\title{
Environmental controls on zooplankton during hydrological periods of flooding and flushing in an Amazonian floodplain lake
}

\author{
Leonardo Fernandes Gomes ${ }^{1, *}$, Ludgero Cardoso Galli Vieira ${ }^{1}$, Carla Albuquerque de Souza ${ }^{1}$, \\ Marie-Paule Bonnet ${ }^{2,3}$ and Alexandre Nascimento de Almeida ${ }^{1}$
}

${ }^{1}$ Faculdade UnB Planaltina, Área Universitária 1, Vila Nossa Senhora de Fátima, 73.345-010 - Planaltina - DF, Brasil.

2 UMR 228 Espace-DEV, IRD Institut de Recherche pour le développement, 34000 Montpellier, France.

3 International Joint Laboratory Observatoire des Changements Environnementaux LMI OCE, IRD - Universidade de Brasília, Campus Universitário Darcy Ribeiro, CEP 70910-900 Brasília, Brazil.

* Corresponding author: leof.ciamb@gmail.com

Received: 08/02/18 Accepted: 11/03/19

\begin{abstract}
Environmental controls on zooplankton during hydrological periods of flooding and flushing in an Amazonian floodplain lake
\end{abstract}

The hydrological regime exerts a strong control on environmental and biological variables in floodplains. To better understand this process, the present study evaluates the influence of environmental variables on zooplankton community structure, focusing on the hydrological variation of the flood pulse. For this purpose, we address the following questions: (i) What is the effect of hydrologic period on environmental characteristics and the structure of zooplankton community? (ii) Do environmental and biological similarities between sampling sites in a lacustrine ecosystem differ within flooding and flushing periods? (iii) How do zooplanktonic organisms respond to environmental gradients? To achieve this work, environmental and biological samples were collected in 20 sampling sites along the Lago Grande do Curuai in March (flooding period) and September (flushing period) of 2013. While some zooplankton taxa showed relationship with some environmental variables, we estimate that the hydrological variation had a higher control over the taxonomic composition of Lago Grande do Curuai. Therefore, the strong flow that promotes connectivity between the habitats in the floodplain lake may also justify the similar pattern of heterogeneity between sampling sites for the zooplankton community in both periods, despite their environmental differences.

Key words: flood pulse, seasonality, hydrology, Lago Grande do Curuai

\section{RESUMO}

Controle ambiental sobre o zooplâncton nos períodos hidrológicos de enchente e vazante em um lago de uma planície de inundação amazônica

O regime hidrológico exerce um forte controle sobre as variáveis ambientais e biológicas em planícies de inundação. Diante disso, o presente estudo avaliou a influência de variáveis ambientais na estruturação da comunidade zooplanctônica diante da variação hidrológica promovida pelo pulso de inundação. Para isso, pretendemos responder as seguintes questões: (i) Qual é o efeito do periodo hidrológico sobre as características ambientais e a estruturação da comunidade zooplanctônica? (ii) A heterogeneidade ambiental e biológica entre os pontos amostrados no ecossistema lacustre contrasta entre os periodos de enchente e vazante? (iii) Como os organismos zooplanctônicos respondem aos gradientes ambientais? Para isso, amostras ambientais e biológicas foram coletadas em 20 unidades amostrais ao longo do Lago Grande do Curuai em março (periodo de enchente) e setembro (periodo de vazante) de 2013. Algumas espécies zooplanctônicas apresentaram relações com as variáveis ambientais. Apesar disso, assumimos que a variação hidrológica teve maior controle sobre a composição taxonômica no Lago Grande do Curuai. Portanto, o forte fluxo que promove a conectividade entre os habitats na planície de inundação do lago também pode justificar o padrão similar de heterogeneidade entre as unidades amostrais em cada periodo hidrológico 
para toda a comunidade zooplanctônica, apesar das diferenças ambientais entre eles.

Palavras chave: Pulso de inundação, sazonalidade, hidrologia, Lago Grande do Curuai

\section{INTRODUCTION}

Floodplains are regions under periodic influence of the overflow of a main river, which occur either through direct precipitation or water of subterranean origin (Junk et al., 1989, 2012). Due to these unique environments, the corresponding ecosystems are among the most diverse and productive ecosystems in the world (Ward et al., 1999; Tockner \& Stanford, 2002; Abrial et al., 2014; Gilbert et al., 2014) and have great importance in the maintenance of biodiversity (Tockner et al., 2000; Bunn \& Arthington, 2002).

Since the publication of Junk et al. (1989), there were several studies related to flood pulse in the Amazon basin. These studies include nutrient and sediment dynamics (Furch \& Junk, 1993) as well as animal and plant species composition associated with the connectivity variation of the floodplain with the main river (Adis \& Mahnert, 1990; Junk \& Piedade, 1993; Thomaz et al.,
2007). Although this approach was established nearly three decades ago, it is still relevant to current studies that highlight the anthropogenic impact on the natural variation of the flood pulse (Isaac et al., 2016) and seek more direct association between environmental factors and biological composition (Cardoso et al., 2017).

The hydrological regime is responsible for the environmental and biological homogenization during the high-water period, as well as an isolation of these areas during the low-water period, allowing for the development of different species composition in more disconnected areas (Taylor et al., 1993; Thomaz et al., 2007). There are several studies highlighting the effects of the flood pulse on different biological communities, including: fish (Arrington et al., 2005; Ortega et al., 2015), aquatic macrophytes (Rooney et al., 2013), phytoplankton (Chaparro et al., 2014) and zooplankton communities (Lansac-Tôha et al., 2014; Kobayashi et al.,

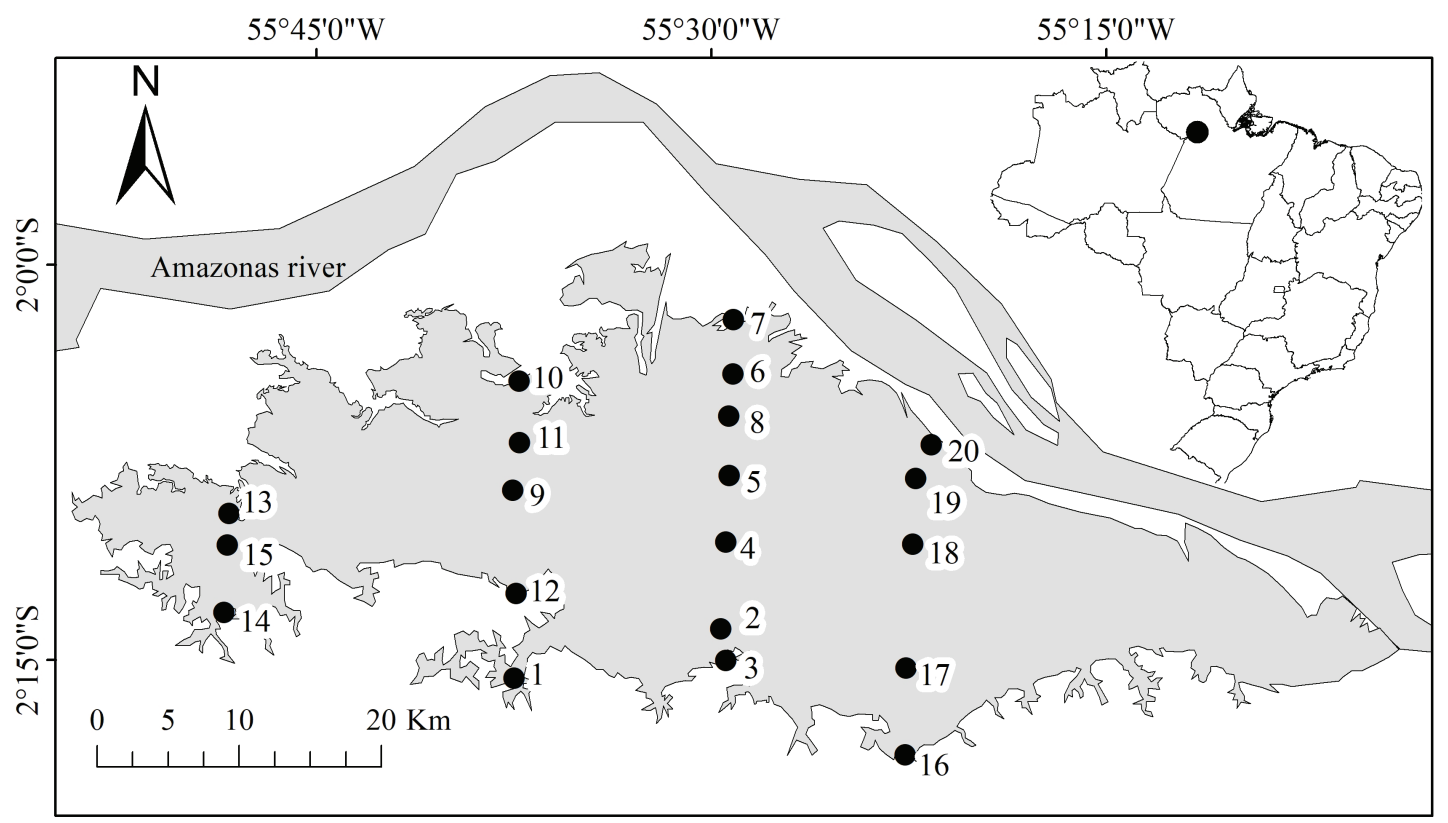

Figure 1. Map of the sampling sites in Lago Grande do Curuai, Brazil. Mapa dos pontos amostrais no Lago Grande do Curuai - Brazil. 
2015; Dias et al., 2016). The planktonic community also responds quickly to variations in environmental conditions (Vieira et al., 2011; Bozelli et al., 2015), mainly related to total nitrogen and phosphorus. Increases in these nutrients increases primary productivity, thus increasing the availability of food for several zooplankton species (Trevisan \& Forsberg, 2007). Furthermore, recent studies show the role of the flood pulse and related environmental variables in structuring zooplankton communities (Bozelli et al., 2015; Goździejewska et al., 2016).

We evaluated the influence of the hydrological variation, promoted by the flood pulse, and environmental variables on structuring the zooplankton community. For this purpose, we aim to answer the following questions: (i) What is the effect of the hydrologic period on the environmental characteristics and zooplankton community structure? (ii) Do environmental and biological similarities between sampling sites in a lacustrine ecosystem differ within flooding and flushing periods? (iii) How do zooplanktonic organisms respond to these environmental gradients?

We hypothesize that both physical and chemical environmental characteristics and zooplankton community structure in the Lago Grande do Curuai have substantial differences between flooding and flushing periods. During the flooding period, we test whether there are more environmental and biological similarities in the lake, and whether some abiotic parameters, such as total nitrogen and total phosphorus, relate to zooplankton species distribution.

\section{MATERIALS AND METHODS}

\section{Study area}

The study was carried out in the floodplain of Lago Grande de Curuai, Pará, Brazil (56.10 ${ }^{\circ}$ to $55.00^{\circ} \mathrm{W}$ and $2.3^{\circ}$ to $1.9^{\circ} \mathrm{S}$ ), located on the south margin of the Amazon river, between the cities of Óbidos, Juruti, Terra Preta and Santarém. The lake is connected to the Amazon River by many channels, in particular during the high-water period. The region presents a monomodal, temporally well-defined sampling site with high and low waters cycles. These water cycles follow the flood pulse of the Amazon river, with the first phase (peak of high waters) occurring from May to July and the second phase (low water minimum) from October to December. The deep-water varies approximately $6 \mathrm{~m}$ (Amorim et al., 2009 ) and the flooded area varies annually between 600 to $2500 \mathrm{~km}^{2}$ (Bonnet et al., 2008).

There were 20 sampling sites along Lago Grande do Curuai (Fig. 1). Biological and environmental samples were collected at each site in March (flooding period) and September (flushing period) of 2013.

\section{Environmental data}

Blue-green algae, dissolved organic carbon, conductivity, fluorescent dissolved organic matter, dissolved oxygen, water pressure, depth, total dissolved solids, temperature, $\mathrm{pH}$ and euphotic zone/depth were all quantified on site using a multiparameter water quality sonde at subsurface (ca $40 \mathrm{~cm})$ (YSY, model EXO2). A Secchi disk was used to evaluate transparency. Samples of alkalinity, chlorophyll- $a$ and total phosphorus were collected from the subsurface ( ca $40 \mathrm{~cm}$ ) and frozen until further analysis. In the laboratory, colorimetry was used to evaluate chlorophyll- $a$ and total phosphorus, chemiluminescence to evaluate total nitrogen, and titration analysis to evaluate alkalinity (APHA-AWWA-WPCF, 1995).

\section{Zooplanktonic community}

Zooplankton were sampled at the subsurface ( $c a$ $50 \mathrm{~cm}$ ) by pumping $300 \mathrm{~L}$ of water through a plankton net of $68 \mu \mathrm{m}$ mesh size. They were subsequently fixed in formaldehyde $(4 \%)$ and buffered with sodium tetraborate. Both quantitative and qualitative analyses were used in the counting and identification of zooplanktonic organisms. In the quantitative analysis, at least 200 individuals of zooplankton (cladocerans, copepods, rotifers and testate amoebae) were counted per sample using a Sedgewick-Rafter chamber and Hensen-Stempel pipette. Subsequently, in the qualitative analysis, the organisms were sampled from the bottom of the beaker with a Pasteur-pipette. All new species were identified 
and their abundances recorded until no new species were identified (method modified from Bottrell et al., 1976). The densities were calculated per $\mathrm{m}^{3}$ of water and the organisms were classified into the lowest possible taxonomic level (usually species) with support of identification keys for each group: cladocerans (Elmoor-Loureiro, 1997), copepods (Silva, 2003; Perbiche-Neves, 2011), rotifers (Koste, 1978), and testate amoebae (Ogden \& Hedley, 1980).

\section{Data analysis}

To verify the differences in the means of the variables and of the zooplanktonic groups between the sample periods (flooding and flushing) we performed a Student's t-test for paired samples. Prior to those analyses, a Detrended Correspondence Analysis (DCA) was performed to verify the dimensions of the environmental and biological gradients. With this technique, if the length of first axis is larger than four, unimodal methods (CA or CCA) are preferable. On the other hand, if the length of first axis is shorter than three, the linear method (PCA or RDA) is preferable. Both types of ordination (unimodal or linear methods) can be used when values are between three and four (Lepš \& Šmilauer, 2003).

To access the relative importance of environmental variables for zooplankton, cladocerans and copepods communities we performed a Redundancy Analysis (RDA, Legendre \& Legendre, 2012), with a Hellinger transformation to abundance data (Legendre \& Gallagher, 2001). We used Canonical Correspondence Analysis (CCA, Legendre \& Legendre, 2012) for the long gradient distribution groups (rotifer and testate amoebae). To find a set of parsimonious environmental variables that significantly contributed to zooplankton community variation we performed a forward selection using the function ordistep (Blanchet et al., 2008) in the vegan package (Oksanen et al., 2013). The variables selected by forward selection were used in all subsequent analyses. The following abbreviations and units of measure were used for the environmental variables: $\mathrm{BGA}=$ Blue-green algae $(\mu \mathrm{g} / \mathrm{L})$, Chlo- $a=$ Chlorophyll- $a(\mu \mathrm{g} / \mathrm{L}), \mathrm{N}=$ Total nitro- gen $(\mu \mathrm{g} / \mathrm{L}), \mathrm{P}=$ Total phosphorus $(\mu \mathrm{g} / \mathrm{L})$, TDS $=$ Total dissolved solids $(\mathrm{mg} / \mathrm{L})$ and Transp = Transparency (m).

We performed a partial RDA with shorter gradients groups (pRDA, cladocerans and copepods) and a partial CCA with long gradients groups (pCCA, rotifers and testate amoebae) to compare the individual contributions of each selected environmental variable to their respective zooplankton group To conduct these analyses, zooplankton density data was inserted as a response variable and each one of the environmental variables was inserted as a predictor, with the effects of the others being removed with the partial RDA. Before pRDA analysis, the biological variables were Hellinger-transformed.

After the DCA first axis length analysis $(<3)$, we conducted a Principal Component Analysis (PCA) with the selected variables to summarize the environmental variation in sampling sites in both flooding and flushing hydrologic periods. Non-Metric Multidimensional Scaling Analysis (NMDS) based on Bray-Curtis distance (Legendre \& Legendre, 2012) was also performed to access the differences in zooplankton community structure and its main groups (cladocerans, copepods, rotifers and testate amoebae).

We tested for differences in environmental characteristics and zooplankton community structure (and its main groups) between flooding and flushing periods using Permutational Multivariate Analysis of Variance Using Distance Matrices (PERMANOVA), with the adonis2 function. To do so, the environmental variables were converted into a Euclidean distance matrix, while the biological ones were converted into a Bray-Curtis distance matrix.

We also performed a multivariate homogeneity analysis on group dispersions (PERMDISP, Anderson, 2006) to calculate the variance (heterogeneity) of zooplankton and the groups and environmental variables between the sampling sites within each hydrologic period. This variance was computed as the average distance of the sites within each hydrological period to its centroid (Anderson, 2006) using the function betadisper.

All analyses were performed with the vegan package (Oksanen et al., 2013), using R programming software (R Development Core Team, 2017). 
Table 1. Total zooplankton richness and abundance (ind $/ \mathrm{m}^{3}$ identified in each period. Riqueza e abundância totais (ind $/ \mathrm{m}^{3}$ ) de zooplâncton em cada período.

\begin{tabular}{lcrcr}
\hline \multirow{1}{*}{ Groups } & \multicolumn{2}{c}{ Flooding } & \multicolumn{2}{c}{ Flushing } \\
\cline { 2 - 5 } Zooplankton & 113 & 1373307 & 86 & 3167902 \\
Cladocerans & 21 & 212734 & 16 & 204626 \\
Copepods & 18 & 855457 & 12 & 1473080 \\
Rotifers & 48 & 201174 & 47 & 1286465 \\
Testates amoebae & 26 & 103942 & 11 & 203731 \\
\hline
\end{tabular}

\section{RESULTS}

In all sampling sites, 143 zooplankton taxa were identified (Table S1, available at http://www. limnetica.net/en/limnetica), summing to a total of 4870567 individuals during both campaigns. While the flushing period showed $230 \%$ more zooplankton individuals than during the flooding period, the flooding period that showed the highest number of species altogether (Table 1). However, the differences were not significant when comparing the means of the abundances of the sampling sites (Table 2). The same pattern was found in relation to zooplankton groups, except for cladocerans, which were more abundant in the flooding period instead of flushing, and rotifers, which had a greater average abundance among sampling sites (Table 2).

The environmental variables that most contributed to variations in the zooplankton community according to forward selection were: total dissolved solids, transparency, blue green algae, total phosphorus, chlorophyll- $a$ and total nitrogen (Table 3). Apart from total nitrogen, these variables varied greatly between flooding and flushing periods, showing clear environmental differences between these periods (Fig. 2A, PERMANOVA: $\left.R^{2}=0.25 ; P<0.01\right)$. Sites in the flooding period presented the highest values of total dissolved solids and total phosphorus, while sites in the flushing period presented the highest values of blue green algae, chlorophyll- $a$ and transparency (Table 3).

As observed in the environmental variables,
Table 2. Comparative paired $t$-test for richness and abundance values between flooding and flushing periods. $\mathrm{DF}=$ Degrees of freedom. Teste t pareado comparativo para os valores de riqueza e abundância entre os periodos de enchente e a vazante. $D F=$ Graus de liberdade.

\begin{tabular}{lcccccc}
\hline \multirow{2}{*}{ Groups } & \multicolumn{3}{c}{ Richness } & \multicolumn{3}{c}{ Abundance } \\
\cline { 2 - 7 } Zooplankton & $\mathbf{t}$ & df & $\boldsymbol{P}$ & $\mathbf{t}$ & $\mathbf{d f}$ & $\boldsymbol{P}$ \\
\hline Cladocerans & 2.86146 & 19 & 0.5612 & -3.1716 & 19 & 0.0050 \\
Copepods & 1.7474 & 19 & 0.0967 & -1.9152 & 19 & 0.0706 \\
Rotifers & -2.1748 & 19 & 0.0424 & -4.1598 & 19 & 0.0005 \\
Testates amoebae & 2.2034 & 19 & 0.0401 & -1.227 & 19 & 0.2348 \\
\hline
\end{tabular}

the structure of the zooplankton community and its groups also differed between periods (Fig. 2 . B-E and Table 4). Regarding the biological variation in sampling sites, cladocerans and rotifers showed heterogeneity within flooding and flushing hydrologic periods (Table 3). However, cladocerans were more heterogeneous during the flushing period, while rotifers were more heterogeneous during the flooding period. When considering the entire zooplankton community, copepods and the testates amoebae groups did not show biological heterogeneity.

Significant associations were found between zooplankton species and environmental variables $(P<0.05$, Fig. 3). With regard to cladocerans, Bosmina tubicen was positively correlated with chlorophyll-a. Diaphanosoma birgei was negatively correlated with chlorophyll- $a$, although presented positive correlation with total phosphorus. Ceriodaphnia cornuta was positively correlated with TDS and total phosphorus and Moina minuta was positively related with total nitrogen. For the copepod group, copepodites and nauplii of the Diaptomidae family were positively correlated with total nitrogen, TDS and total phosphorus. Thermocyclops decipiens was negatively correlated with total phosphorus and nauplii of Cyclopidae family was negatively correlated with TDS and positively correlated with BGA (Fig. 3). For rotifers, Bdelloidea presented a positive correlation with BGA, chlorophyll- $a$ and total nitrogen; on the other hand, Brachionus falcatus 
चี चै ट्व की को

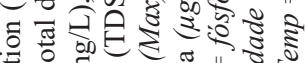

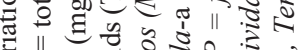

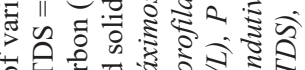
पी

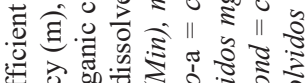

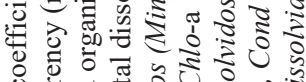
$\circ$ ०

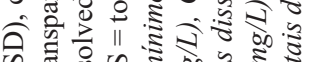

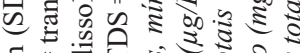
을. ज记

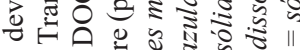

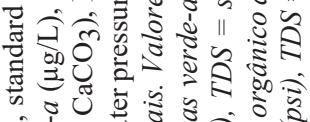

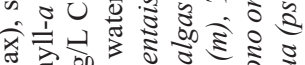

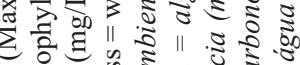
के

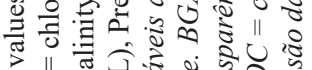

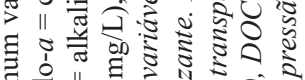
11

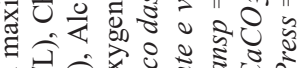

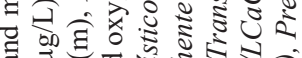

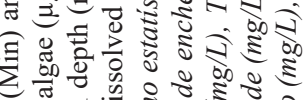

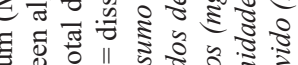
. द

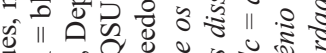
ची 论

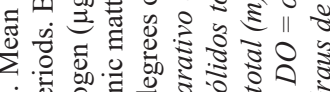
पे

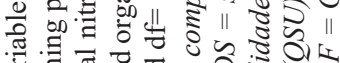

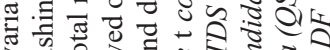
要 응

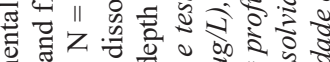

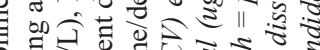

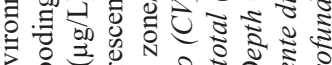
掉 एक

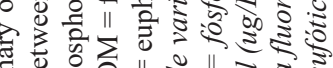
月0.

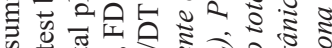

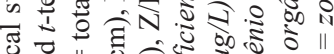

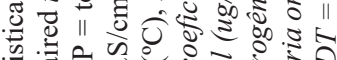

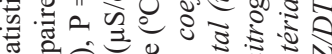
के

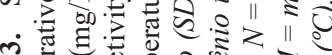

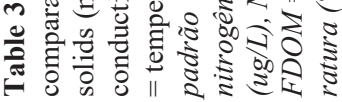

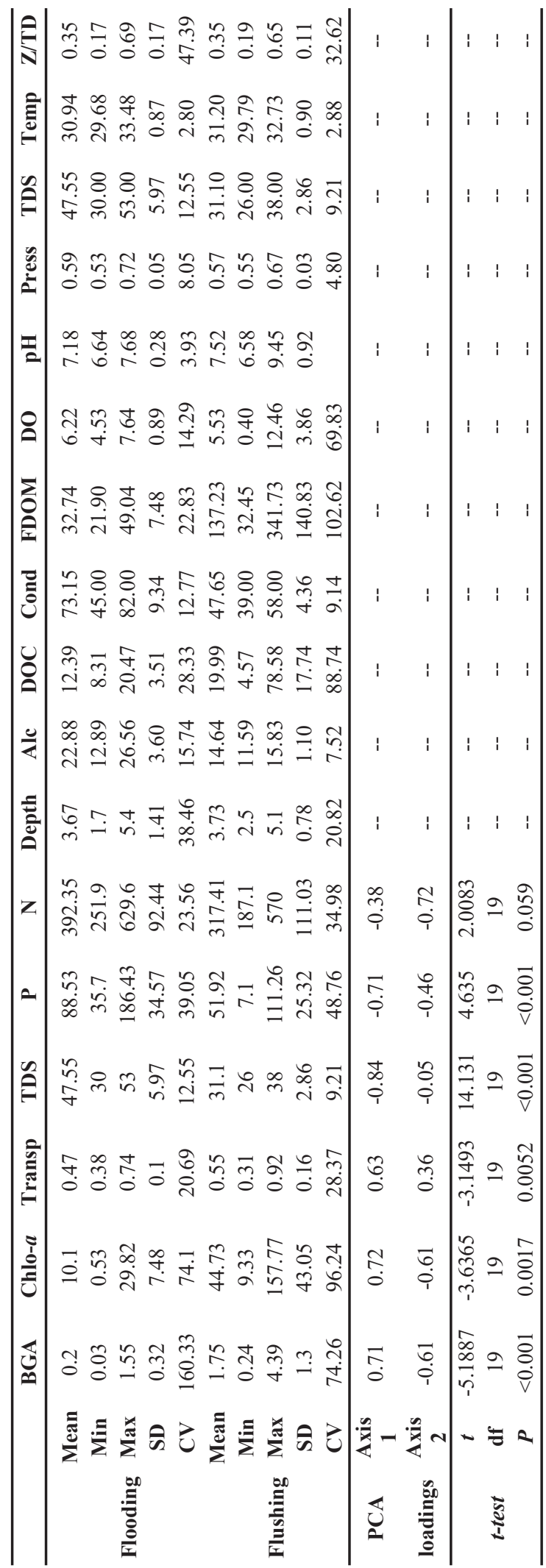



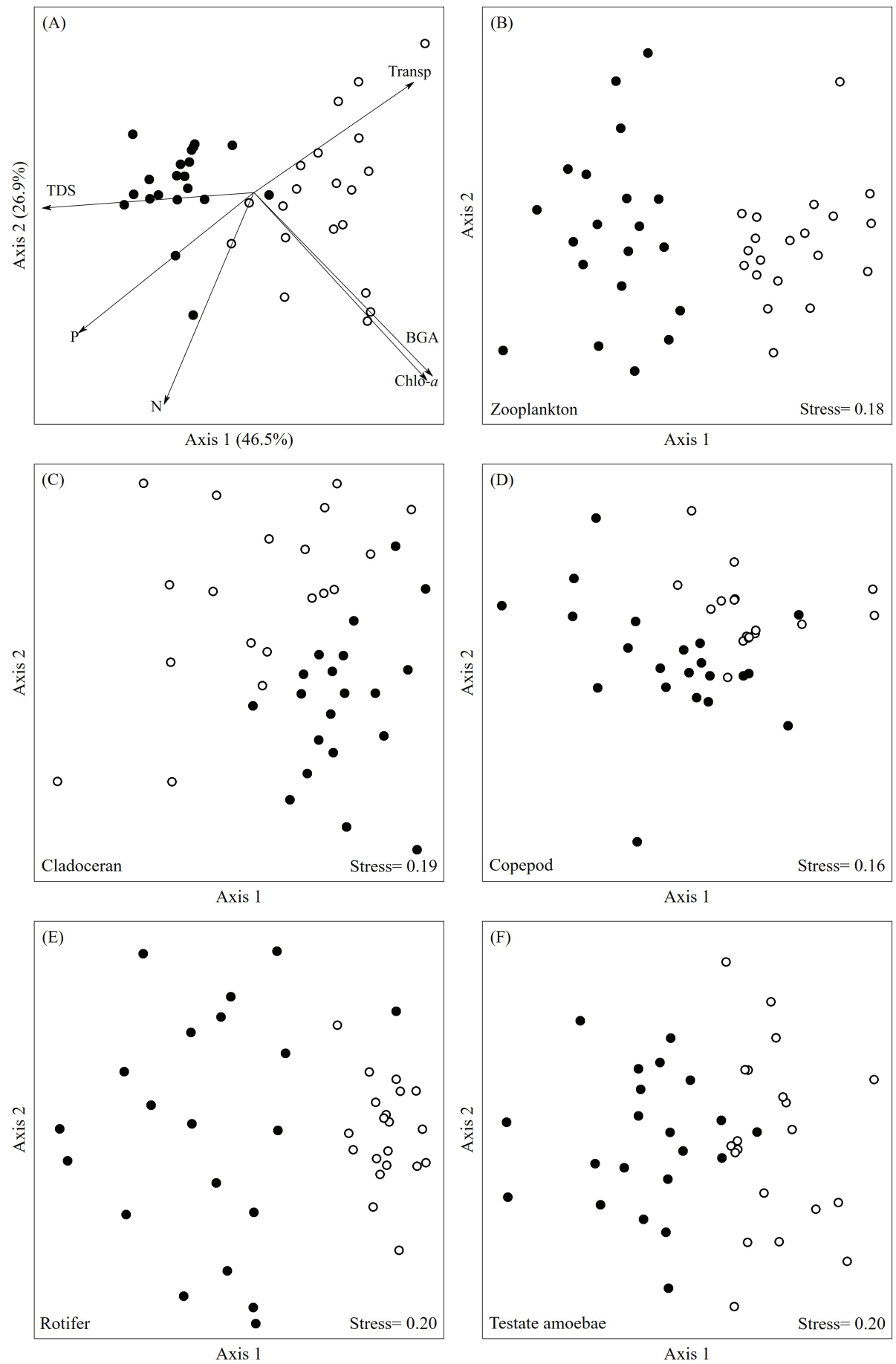

Figure 2. PCA of environmental variables (A) and the NMDS of zooplankton community and its main groups (B to F). Black circles: sites in flooding period; white circles: sites in flushing period. BGA = Blue-green algae $(\mu \mathrm{g} / \mathrm{L}), \mathrm{Chlo}-a=\mathrm{Chlorophyll-}-a(\mu \mathrm{g} / \mathrm{L}), \mathrm{N}=$ Total nitrogen $(\mu \mathrm{g} / \mathrm{L}), \mathrm{P}=$ Total phosphorus $(\mu \mathrm{g} / \mathrm{L})$, TDS $=$ Total dissolved solids $(\mathrm{mg} / \mathrm{L})$ and Transp $=$ Transparency $(\mathrm{m}) . P C A$ das variáveis ambientais (A) e NMDS da comunidade zooplanctônica e seus principais grupos (B a F). Círculos pretos: pontos no período de enchente; círculos brancos: pontos no periodo de vazante. $B G A=$ Algas verde-azuladas $(\mu g / L), C h l o-a=C l o r o f i l a-a ~(\mu g / L), N=$ Nitrogênio total $(u g / L), P=$ Fósforo total $(u g / L), T D S=$ Sólidos totais dissolvidos $(\mathrm{mg} / \mathrm{L})$ and Transp = Transparência $(\mathrm{m})$. 
was negatively related with the same variables; Brachionus zahniseri positively correlated with transparency. Keratella Americana, Colurella obtuse, Lecane submagna and Keratella lenzi positively correlated with chlorophyll- $a$, total nitrogen and phosphorus. Finally, regarding the testate amoebae group, Trinema lineare positively correlated with chlorophyll- $a$ and BGA, Lesquereusia globulosa positively related with TDS and Difflugia difficilis positively correlated with TDS and total phosphorus (Fig. 3). Therefore, although the environmental variables are important for the biological composition of the sampling sites, it should be emphasized that individually, the TDS content had the highest correlation with the distribution of cladocerans, copepods and rotifers according to pRDA and pCCA analyses (Table S2, available at http://www. limnetica.net/en/limnetica).

\section{DISCUSSION}

\section{Biological and environmental differences between hydrological periods}

Our results show strong environmental and biological distinctions between both hydrological periods. In this sense, total dissolved solids, total nitrogen, and total phosphorus were strongly associated with the flooding period. This result is likely due to waters from the Amazon river that enter Lago Grande do Curuai and flood in areas in the aquatic/terrestrial transition zone. This process brings a lot of suspended solids and organic matter into the lake (Junk et al., 1989; Bonnet et al., 2008; Wantzen et al., 2008; Junk et al., 2012).

On the other hand, the flushing period had a strong association with transparency, BGA, and chlorophyll- $a$. As the water level in the lake begins to decrease, the influence of the Amazon River on the region becomes smaller. In addition, sedimentation of suspended solids and organic matter consumption by biological organisms naturally occurs (Wantzen et al., 2008). For this reason, these hydrological variations have also been studied in other aquatic ecosystems, including Mediterranean wetlands (Gilbert et al., 2014).

Biological differences between hydrological
Table 4. Resultados da Análise multivariada permutacional de variância usando matrizes de distância (PERMANOVA) e Betadisper para toda a comunidade zooplanctônica e por grupos. Diferenças significativas estão em negrito. Results of the Permutational Multivariate Analysis of Variance using distance matrices (PERMANOVA) and Betadisper for all zooplankton community and groups. Those data with significant differences are bolded.

\begin{tabular}{lccccc}
\hline & \multicolumn{2}{c}{ PERMANOVA } & \multicolumn{3}{c}{ PERMDISP } \\
\cline { 2 - 6 } \multicolumn{1}{c}{ Groups } & $\boldsymbol{R}^{\mathbf{2}}$ & $\boldsymbol{P}$ & Flooding & Flushing & $\boldsymbol{P}$ \\
\hline \multirow{2}{*}{ Zooplankton } & $\mathbf{0 . 1 7}$ & 0.001 & 0.36 & 0.26 & 0.089 \\
Cladocerans & $\mathbf{0 . 1 1}$ & 0.001 & $\mathbf{0 . 3 7}$ & $\mathbf{0 . 6 0}$ & $\mathbf{0 . 0 2 5}$ \\
Copepods & $\mathbf{0 . 1 7}$ & 0.001 & 0.39 & 0.24 & 0.091 \\
Rotifers & $\mathbf{0 . 1 5}$ & 0.001 & $\mathbf{0 . 7 5}$ & $\mathbf{0 . 2 7}$ & $\mathbf{0 . 0 0 1}$ \\
Testates amoebae & $\mathbf{0 . 1 2}$ & 0.001 & 0.36 & 0.50 & 0.338 \\
\hline
\end{tabular}

periods were also evident. As planktonic organisms have reduced size and life cycles, they are usually more susceptible to environmental effects than larger size groups (Bie et al., 2012; Dias et al., 2016). Therefore, the same hydrological regime that influenced the environment may have directly influenced the zooplanktonic community, which can be passively transported by the water flow, or indirectly, through the modification of environmental variables or other biological groups that were also strongly able to influence the community composition of zooplankton. For example, as several zooplanktonic groups feed on phytoplankton organisms, and the flushing period had high values of chlorophyll- $a$ and transparency values, such factors may have been associated with the expressive abundance of organisms during this hydrological period.

Finally, there are three important points that should be considered in our study. The first point concerns how the zooplankton were collected at $50 \mathrm{~cm}$ depth and therefore do not represent the entire water column. Zooplankton organisms undergo vertical migration in the water column; it is therefore possible that some organisms have not been collected. On the other hand, the samples were standardized between the seasons (zooplankton collected at $50 \mathrm{~cm}$ depth) and the depth of the sample points varied slightly between flooding and flushing (mean values of 3.67 and $3.73 \mathrm{~m}$, 

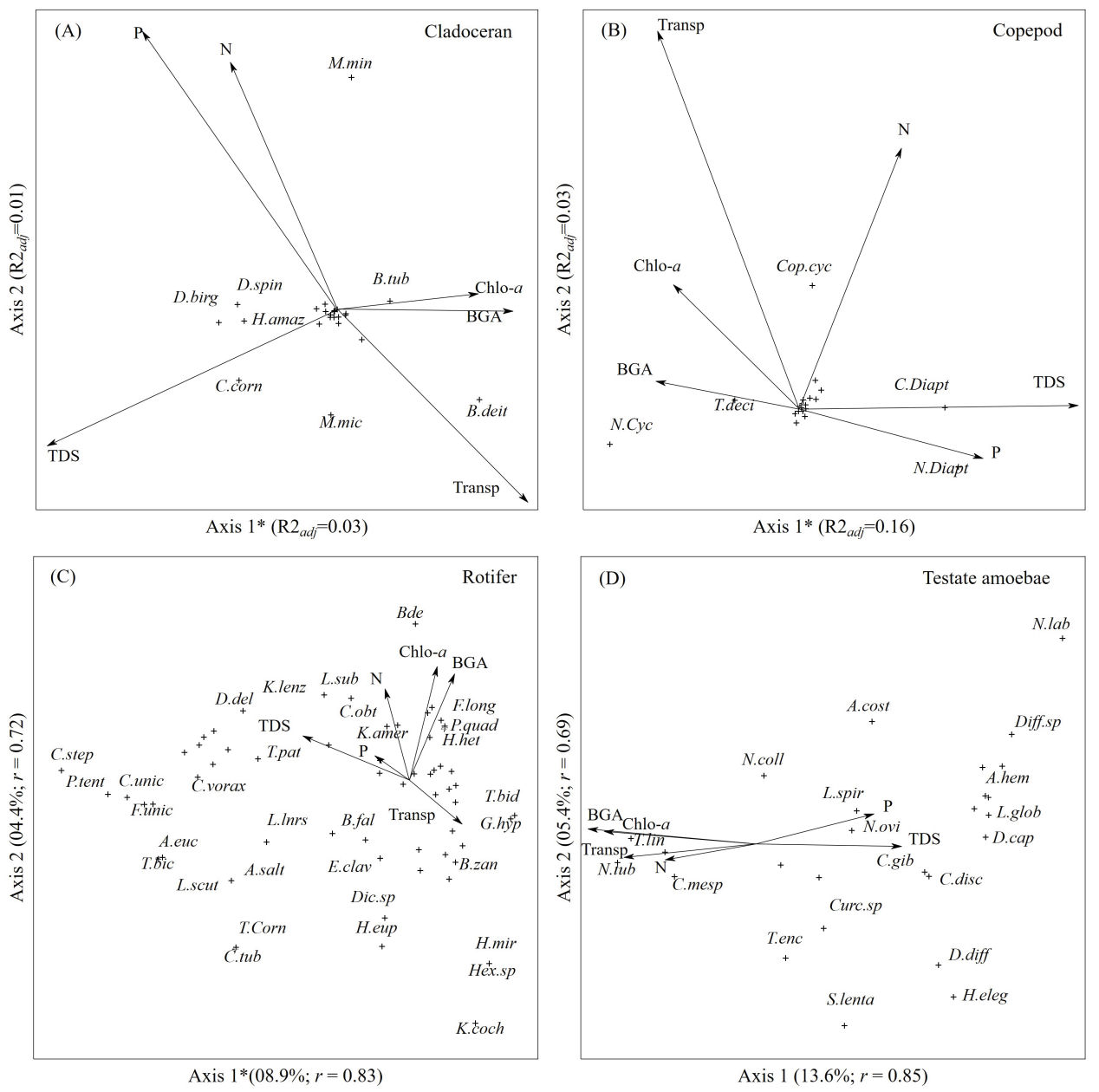

Figure 3. Redundancy Analysis (RDA; A and B) and Canonical Correspondence Analysis (CCA; C and D) of the species in relation to the environmental variables. BGA = Blue-green algae $(\mu \mathrm{g} / \mathrm{L})$, Chlo- $a=$ Chlorophyll- $a(\mu \mathrm{g} / \mathrm{L}), \mathrm{N}=$ Total nitrogen $(\mu \mathrm{g} / \mathrm{L}), \mathrm{P}=\mathrm{Total}$ phosphorus $(\mu \mathrm{g} / \mathrm{L})$, TDS $=$ Total dissolved solids $(\mathrm{mg} / \mathrm{L})$ and Transp $=$ Transparency $(\mathrm{m})$. For acronyms of species, see supplementary material. All analyses exhibited significance $(P<0.05)$. RDA figures presented the following values of $\mathrm{R}^{2}$ adj: $\mathrm{A}=0.19 ; \mathrm{B}=0.38$. Significant axes have an asterisk (*). Análise de redundância (RDA, A e B) e Análise de Correspondência Canônica (CCA, C e D) das

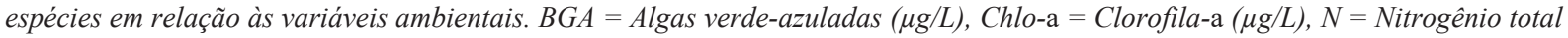
(ug/L), P = Fósforo total (ug/L), TDS = Sólidos totais dissolvidos $(\mathrm{mg} / \mathrm{L})$ and Transp = Transparência (m). Para os acrônimos das espécies, veja o material suplementar. Todas as análises foram significativas $(\mathrm{P}<0.05)$. As figuras da RDA apresentaram os seguintes valores de $R^{2}$ adj:A $=0.19 ; B=0.38$. Eixos significativos apresentam asterisco (*).

respectively; Table 3). Second, the chlorophyll- $a$ results should be considered with caution because they were collected at the same depth $(40 \mathrm{~cm})$ at every sampling location. However, depending on the transparency of the water, chlorophyll- $a$ concentrations would vary along the water column. Third, there is the possibility that small rotifers and testate amoebae would not be sufficiently caught because of the mesh used $(68 \mu \mathrm{m})$.
The richness and density of rotifers and testate amoebae should be interpreted with caution.

\section{Biological and environmental differences between sampling sites within each hydrologi- cal period}

We expected a higher environmental heterogeneity between sampling sites within the flooding 
period, since it followed an extremely heterogeneous low water period. Our expectations were based on the dynamics of high and low waters periods. High water periods allow for high connectivity between habitats and organisms and promote a strong homogenization of the environmental characteristics of the entire region (Thomaz et al., 2007), while the low water periods indicate less connectivity between floodplain regions and, habitats consequently tend to be more heterogeneous (Simões et al., 2013; Bozelli et al., 2015). However, our expectations were not confirmed and both periods (flooding and flushing) were equally heterogeneous between sampling sites. We attributed this result to the strong flow from the Amazon River, which quickly homogenizes the environmental characteristics that were heterogenous in the low water period.

Regarding the biological heterogeneity between sites for each zooplanktonic group, we show here that some taxa are more able to withstand the flood pulse. This is mainly due to characteristics that allow these organisms to survive in certain environments (Bunn \& Arthington, 2002; Mouzinho et al., 2010; Abrial et al., 2014). For example, the size of certain organisms allows them to deal with environmental conditions through dispersion (Dias et al., 2016). These factors may justify the composition of many biological groups; in our study, testates amoebae exhibited high richness, yet showed low abundance compared to the other zooplankton groups. As testates amoebae have limited dispersion capacity and more susceptibility to the environment than other groups with larger body sizes and dispersion capacity (Dias et $a l ., 2016)$, they effectively responded to environmental variation, mainly TDS. In addition, this community showed higher taxonomic richness in the flushing period, in which TDS presented the highest average values.

Copepods also did not present heterogeneity in sampling sites within hydrological periods, which may be due to their longer average lifetimes, as well as their greater ease of dispersion due to their corporeal size. Therefore, this group is less subject to environmental variations than the other groups (Dias et al., 2016). Notably, in lacustrine environments (Echaniz \& Vignatti, 2017), copepod abundance was the most repre- sentative for both periods, and higher during the flushing period. Therefore, we assume that in general, and as evidenced for invertebrates in other studies (Dias et al., 2016; Goździejewska et al., 2016), hydrological conditions have a strong association with the community composition of zooplankton in floodplains.

The cladocera community exhibited more heterogeneity between sampling sites within the flushing period because they are less suited to large watercourses, tending to shelter in regions with lower water flow and where there are natural barriers against predators, such as in macrophytes banks (Castilho-Noll et al., 2010; Montiel-Martínez et al., 2015). On the other hand, rotifers showed more heterogeneity between sampling sites within the flooding period. However, the abundance of these organisms was higher by about six times during the flushing period, implying that the increase in primary productivity may have been a determining factor. This result could be due to the adaptive strategies of those taxa that are related to each hydrological period (Paidere, 2009; Chaparro et al., 2014). Rotifers are evidenced as an extremely cosmopolitan group. Furthermore, their ability to rapidly reproduce and their smaller body sizes would influence the dispersion capacity, implying that they may in fact be more subject to environmental variations than the other groups (Dias et al., 2016).

\section{Biological and environmental associations}

The pulse of water originating from the Amazon River to the Lago Grande do Curuai may have favoured not only the increase in organic matter and suspended solids, but also the increase in species richness for all groups, as it would change the movement of organisms and lead many of them to the surface. In addition, despite the predominance of hydrology over biological factors in this study, many species were directly related to certain environmental variables.

Most zooplanktonic groups have appropriate reproduction strategies to deal with environmental conditions. For example, cladocerans, rotifers, and copepods produce diapausing eggs that persist in the sediment until conditions are adequate for hatching (Xu et al., 2017, García-Roger \& Ortells, 
2017, Makino et al., 2013). This quality is what makes these organisms effective in responding to environmental changes (Payne, 2013).

In fact, some species are associated with certain environmental variables. For one, Moina minuta are associated with environments with higher concentration of $\mathrm{N}, \mathrm{P}$ and chlorophyll- $a$ (Vieira et al., 2011). Additionally, Diaphanosoma spinulosum is found in environments with relatively lower nutrients and chlorophyll- $a$ (Vieira et al., 2011), while Keratella americana is related to chlorophyll- $a$ (Rodríguez \& Matsumura-Tundisi, 2000).

In this study, the larval and juvenile stages of copepods left a strong signature. Considering this finding, the Cyclopidae family presents diapause between their juvenile and adult stage (Lampert \& Sommer, 2007). The high abundance of larval and juvenile copepods stages in this work can be justified by such conditions. The association between Cyclopidae and algae, for example, may have occurred because individuals of this family are typically herbivores in their juvenile stages, yet may feed on other zooplanktonic organisms in the adult stage (Adrian \& Frost, 1993). The Cyclopidae family is related to the Diaptomidae family, although the latter is more associated with herbivorism and may have differentiated feeding habits depending on the species (Lampert \& Sommer, 2007). Therefore, in the case of copepods, different feeding habits and experiences can explain their differences in correspondence to environmental variables.

\section{CONCLUSION}

In this study, we suggest that hydrological periods, in particular flooding and flushing, were largely responsible for structuring the zooplanktonic community in the Amazonian floodplain of Lago Grande do Curuai. In addition, the environmental variables changed according to the hydrological period in the lake.

The species tested in this work related to the environmental variables. The strong flow that promotes connectivity between habitats in the floodplain may also explain the similar pattern of biological heterogeneity found in sampling sites within both hydrologic periods, despite the envi- ronmental differences between them.

The results found in this study are highly valuable, as certain zooplankton species have the potential to respond to environmental variations. Considering these findings, it is important for the community to establish permanent biomonitoring programs in all hydrological periods in Lago Grande do Curuai, which would highlight the importance of considering environmental effects on the community.

\section{ACKNOWLEDGEMENTS}

The authors thank the Coordenação de Aperfeiçoamento de Pessoal de Nível Superior (CAPES) for providing financial assistance to L.F.G. and C.A.S. LCGV was supported by productivity fellowships of Conselho Nacional de Desenvolvimento Científico e Tecnológico $(\mathrm{CNPq})$. We also thank the Fondation pour la Recherche sur la Biodiversité (FRB) and the Conselho Nacional de Desenvolvimento Científico e Tecnológico (CNPq); these groups, in partnership with Institut de Recherche pour le Développement (IRD), financed the project number of process: 490634/2013-3.

\section{REFERENCES}

ABRIAL, E., A. P. RABUfFETTI, L. A. ESPINOLA, M. L. AMSLER, M. C. M. BLETTLER \& A. R. PAIRA. 2014. Influence of hydrological changes on the fish community in two lotic environments of the Middle Parana Floodplain, Argentina. Aquatic Ecolo$g y, 48$ (3): 337-349. DOI: $10.1007 / \mathrm{s} 10452-$ 014-9488-X

ADIS, J. \& V. MAHNERT. 1990. On the species composition of Pseudoscorpiones (Arachnida) from Amazonian dryland and inundation forest in Brazil. Revue suisse de zoologie, 97 (1): 49-53. DOI: 10.5962/bhl.part.79724

ADRIAN, R. \& T. M. FROST. 1993. Omnivory in cyclopoid copepods: comparisons of algae and invertebrates as food for three, differenfly sized species. Journal of Plankton Research, 15 (6): 643-658. DOI: 10.1093/plankt/15.6.643

AMORIM, M. A., P. F. M. TURCQ, B. J. TURCQ \& R. C. CORDEIRO. 2009. Origem e dinâmi- 
ca da deposição dos sedimentos superficiais na Várzea do Lago Grande de Curuai, Pará, Brasil. Acta Amazonica, 39 (1): 165-172. DOI: 10.1590/S0044-59672009000100016

ANDERSON, M. J. 2006. Distance-Based Tests for homogeneity of multivariate dispersions. Biometrics, 62 (1): 245-253. DOI: 10.1111/j. 1541-0420.2005.00440.x

APHA-AWWA-WPCF. 1995. Standard methods for the examination of water and wastewater. APHA. USA.

ARRINGTON, D. A., K. O. WINEMILLER \& C. A. LAYMAN. 2005. Community assembly at the patch scale in a species rich tropical river. Oecologia, 144 (1): 157-167. DOI: 10.1007/ s00442-005-0014-7

BIE, T., L. MEESTER, L. BRENDONCK, K. MARTENS, B. GODDEERIS, D. ERCKEN, H. HAMPEL, L. DENYS, L. VANHECKE, K. GUCHT, J. WICHELEN, W. VYVERMAN \& S. A. J. DECLERCK. 2012. Body size and dispersal mode as key traits determining metacommunity structure of aquatic organisms. Ecology Letters, 15 (7): 740-747. DOI: $10.1111 /$ j.1461-0248.2012.01794.x

BLANCHET, F. G., P. LEGENDRE \& D. BORCARD. 2008. Forward selection of explanatory variables. Ecology, 89 (9): 2623-2632. DOI: 10.1890/07-0986.1

BONNET, M. P., G. BARROUX, J. M. MARTINEZ, F. SEYLER, P. MOREIRA-TURCQ, G. COCHONNEAU, J. M. MELACK, G. BOAVENTURA, L. MAURICE-BOURGOIN, J. G. LEÓN, E. ROUX, S. CALMANT, P. KOSUTH, J. L. GUYOT \& P. SEYLER. 2008. Floodplain hydrology in an Amazon floodplain lake (Lago Grande de Curuaí). Journal of Hydrology, 349 (1-2): 18-30. DOI: $10.1016 /$ j.jhydrol.2007.10.055

BOTTRELL, H. H., A. DUNCAN, Z. M. GLIWICZ, E. GRYGIEREK, A. HERZIG, A. HILLBRICHTILKOWSKA, H. KURASAWA, P. LARSSON \& T. WEGLENSKA. 1976. Review of some problems in zooplankton production studies. Norwegian Journal of Zoology, 24 (4): 419-456.

BOZELLI, R. L., S. M. THOMAZ, A. A. PADIAL, P. M. LOPES \& L. M. BINI. 2015. Floods decrease zooplankton beta diversity and environmental heterogeneity in an Amazonian floodplain system. Hydrobiologia, 753 (1): 233-241. DOI: 10.1007/s10750-015-2209-1

BUNN, S. E. \& A. H. ARTHINGTON. 2002. Basic Principles and Ecological Consequences of Altered Flow Regimes for Aquatic Biodiversity. Environmental Management, 30 (4): 492-507. DOI: 10.1007/s00267-002-2737-0

CARDOSO, S. J., J. C. NABOUT, V. F. FARJALLA, P. M. LOPES, R. L. BOZELLI, V. L. M. HUSZAR \& F. ROLAND. 2017. Environmental factors driving phytoplankton taxonomic and functional diversity in Amazonian floodplain lakes. Hydrobiologia, 802 (1): 115-130. DOI: 10.1007/s10750-017-3244-X

CASTILHO-NOLL, M. S. M., C. F. CÂMARA, M. F. CHICONE \& É. H. SHIBATA. 2010. Pelagic and littoral cladocerans (Crustacea, Anomopoda and Ctenopoda) from reservoirs of the Northwest of São Paulo State, Brazil. Biota Neotropica, 10 (1): 21-30. DOI: 10.1590/S1676-06032010000100001

CHAPARRO, G., M. S. FONTANARROSA, M. R. SCHIAFFINO, P. DE TEZANOS PINTO \& I. O'FARRELL. 2014. Seasonal-dependence in the responses of biological communities to flood pulses in warm temperate floodplain lakes: implications for the "alternative stable states" model. Aquatic Sciences, 76 (4): 579-594. DOI: 10.1007/s00027-014-0356-5

DIAS, J. D., N. R. SIMÕES, M. MEERHOFF, F. A. LANSAC-TÔHA, L. F. M. VELHO \& C. C. BONECKER. 2016. Hydrological dynamics drives zooplankton metacommunity structure in a Neotropical floodplain. Hydrobiologia, 781 (1): 109-125. DOI: 10.1007/s10750016-2827-2

ECHANIZ, S. A. \& A. M. VIGNATTI. 2017. The zooplankton of the shallow lakes of the semi-arid region of southern South America. Annales de Limnologie - International Journal of Limnology, 53: 345-360. DOI: 10.1051/ limn/2017018

ELMOOR-LOUREIRO, L. M. A. 1997. Manual de identificação de cladóceros límnicos do Brasil. Editora Universa. Brazil.

FURCH, K. \& W. J. JUNK. 1993. Seasonal nutrient dynamics in an Amazonian floodplain lake. Archiv für Hydrobiologie, 128 (3): 
$277-285$.

GARCÍA-ROGER, E. M. \& R. ORTELLS. 2017. Trade-offs in rotifer diapausing egg traits: survival, hatching, and lipid content. Hydrobiologia, 805 (1): 1-12. DOI: 10.1007/s10750017-3317-x

GILBERT, J. D., DE VICENTE, I., ORTEGA, F., JIMÉNEZ-MELERO, R., PARRA, G. \& F. GUERRERO. 2014. A comprehensive evaluation of the crustacean assemblages in southern Iberian Mediterranean wetlands. Journal of limnology, 74 (1). DOI: 10.4081/ jlimnol.2014.993

GOŹDZIEJEWSKA，A., K. GLIŃSKA-LEWCZUK, K. OBOLEWSKI, M. GRZYBOWSKI, R. KUJAWA, S. LEW \& $\mathrm{M}$. GRABOWSKA. 2016. Effects of lateral connectivity on zooplankton community structure in floodplain lakes. Hydrobiologia, 774 (1): 7-21. DOI: 10.1007/s10750-016-2724-8

ISAAC, V. J., L. CASTELLO, P.R.B. SANTOS \& M. L. RUFFINO. 2016. Seasonal and interannual dynamics of river-floodplain multispecies fisheries in relation to flood pulses in the Lower Amazon. Fisheries Research, 183: 352-359. DOI: 10.1016/j.fishres.2016.06.017 JUNK, W. J., P. B. BAYLEY \& R. E. SPARKS. 1989. The flood pulse concept in river-floodplain systems. Canadian special publication of fisheries and aquatic sciences, 106 (1): 110-127.

JUNK, W. J. \& M. T. F. PIEDADE. 1993. Herbaceous plants of the Amazon floodplain near Manaus: Species diversity and adaptations to the flood pulse. AMAZONIANA, 12 (3-4): 467-484.

JUNK, W. J., M. T. F. PIEDADE, J. SCHÖNGART \& F. WITTMANN. 2012. A classification of major natural habitats of Amazonian white-water river floodplains (várzeas). Wetlands Ecology and Management, 20 (6): 461-475. DOI: 10.1007/s11273-012-9268-0

KOBAYASHI, T., T. J. RALPH, D. S. RYDER, S. J. HUNTER, R. J. SHIEL \& H. SEGERS. 2015. Spatial dissimilarities in plankton structure and function during flood pulses in a semi-arid floodplain wetland system. Hydrobiologia, 747 (1): 19-31. DOI: 10.1007/s10750014-2119-7
KOSTE, W. 1978. Rotatoria. Die Radertiere Mitteleuropas (Uberorderung Monogonata). Ein Bestimmungswert, begrundet von Max Voigt. Gebruder Borntraeger, Berlin, Stuttgart. LAMPERT, W. \& U. SOMMER. 2007. Limnoecology. Oxford University Press Inc.

LANSAC-TÔHA, F., L. VELHO, D. COSTA, N. SIMÕES \& G. ALVES. 2014. Structure of the testate amoebae community in different habitats in a neotropical floodplain. Brazilian Journal of Biology, 74 (1): 181-190. DOI: 10.1590/1519-6984.24912

LEGENDRE, P. \& E. GALLAGHER. 2001. Ecologically meaningful transformations for ordination of species data. Oecologia, 129 (2): 271-280. DOI: 10.1007/s004420100716

LEGENDRE, P. \& L. LEGENDRE. 2012. Numerical ecology. Elsevier.

LEPŠ, J. \& P. ŠMILAUER. 2003. Multivariate analysis of ecological data using CANOCO. Cambridge university press.

MAKINO, W., H. OHTSUKI \& J. URABE. 2013. Finding copepod footprints: a protocol for molecular identification of diapausing eggs in lake sediments. Limnology, 14 (3): 269-282. DOI: 10.1007/s10201-013-0404-1

MONTIEL-MARTÍNEZ, A., J. CIROS-PÉREZ \& G. CORKIDI. 2015. Littoral zooplankton-water hyacinth interactions: habitat or refuge? Hydrobiologia, 755 (1): 173-182. DOI: $10.1007 / \mathrm{s} 10750-015-2231-3$

MOUZINHO, J. R. C., C. R. V. DA FONSECA $\&$ M. L. L. BARBOSA. 2010. The influence of flood pulses on the reproductive strategy of two species of passalid beetle in the fluvial archipelago of Anavilhanas, Amazon, Brazil. Journal of Natural History, 44 (9-10): 589-600. DOI: 10.1080/00222930903384758

OGDEN, G. G., \& R. H. HEDLEY. 1980. An atlas of freshwater testate amoebae. Oxford University Press.

OKSANEN, J., F. G. BLANCHET, R. KINDT, P. LEGENDRE, P. R. MINCHIN, R. B. O'HARA, G. L. SIMPSON, P. SOLYMOS, M. H. H. STEVENS \& H. WAGNER. 2013. vegan: Community Ecology Package.

ORTEGA, J. C. G., R. M. DIAS, A. C. PETRY, E. F. OLIVEIRA \& A. A. AGOSTINHO. 2015. Spatio-temporal organization patterns 
in the fish assemblages of a Neotropical floodplain. Hydrobiologia, 745 (1): 31-41. DOI: 10.1007/s10750-014-2089-9

PAIDERE, J. 2009. Influence of flooding frequency on zooplankton in the floodplains of the Daugava River (Latvia). Acta Zoologica Lituanica, 19 (4): 306-313. DOI: 10.2478/v10043-009-0036-1

PAYNE, R. J. 2013. Seven reasons why protists make useful bioindicators. Acta Protozoologica, 52 (3): 105-113.

PERBICHE-NEVES, G. 2011. Copépodes planctônicos (Crustacea, Calanoida e Cyclopoida) em reservatórios e trechos lóticos da bacia do rio da Prata (Brasil, Paraguai, Argentina e Uruguai): taxonomia, distribuição geográfica e alguns atributos ecológicos. Ph.D. Thesis. Universidade Estadual Paulista-UNESP, Brazil.

R DEVELOPMENT CORE TEAM. 2017. R: A language and environment for statistical computing. R Foundation for Statistical Computing, Vienna, Austria.

RODRÍGUEZ, M. P. \& T. MATSUMURA-TUNDISI. 2000. Variation of density, species composition and dominance of Rotifers at a shallow tropical reservoir (Broa reservoir, SP, Brazil) in a short scale time. Revista Brasileira de Biologia, 60 (1): 01-09. DOI: 10.1590/S0034-71082000000100002

ROONEY, R. C., C. CARLI \& S. E. BAYLEY. 2013. River Connectivity Affects Submerged and Floating Aquatic Vegetation in Floodplain Wetlands. Wetlands, 33 (6): 1165-1177. DOI: $10.1007 / \mathrm{s} 13157-013-0471-4$

SIMÕES, N. R., J. D. DIAS, C. M. LEAL, L. DE SOUZA MAGALHÃES BRAGHIN, F.A. LANSAC-TÔHA \& C. C. BONECKER. 2013. Floods control the influence of environmental gradients on the diversity of zooplankton communities in a neotropical floodplain. Aquatic Sciences, 75 (4): 607-617. DOI: 10.1007/s00027-013-0304-9

SILVA, W. M. D. 2003. Diversidade dos Cyclopoida (Copepoda, Crustácea) de água doce do estado de São Paulo: taxonomia, ecologia e genética. Ph.D. Thesis. Universidade Federal de São Carlos, Brazil.
TAYLOR, P. D., L. FAHRIG, K. HENEIN \& G. MERRIAM. 1993. Connectivity is a vital element of landscape structure. Oikos, 68 (3): 571.

THOMAZ, S. M., L. M. BINI \& R. L. BOZELLI. 2007. Floods increase similarity among aquatic habitats in river-floodplain systems. Hydrobiologia, 579 (1): 1-13. DOI: 10.1007/s10750006-0285-y

TOCKNER, K., F. MALARD \& J. V. WARD. 2000. An extension of the flood pulse concept. Hydrological Processes, 14 (16-17): 2861-2883. DOI: 10.1002/1099-1085(200011/ 12) $14: 16 / 173.0 . \mathrm{CO} ; 2-\mathrm{F}$

TOCKNER, K. \& J. A. STANFORD. 2002. Riverine flood plains: present state and future trends. Environmental Conservation, 29 (3): 308-330. DOI: 10.1017/S037689290200022X

TREVISAN, G. V. \& B. R. FORSBERG. 2007. Relationships among nitrogen and total phosphorus, algal biomass and zooplankton density in the central Amazonia lakes. Hydrobiologia, 586 (1): 357-365. DOI: 10.1007/s10750-0070705-7

VIEIRA, A. C. B., A. M. A. MEDEIROS, L. L. RIBEIRO \& M. C. CRISPIM. 2011. Population dynamics of Moina minuta Hansen (1899), Ceriodaphnia cornuta Sars (1886), and Diaphanosoma spinulosum Herbst (1967) (Crustacea: Branchiopoda) in different nutrients ( $\mathrm{N}$ and $\mathrm{P}$ ) concentration ranges. Acta Limnologica Brasiliensia, 23 (1): 48-56.

WANTZEN, K. M., W. J. JUNK \& K.-O. ROTHHAUPT. 2008. An extension of the floodpulse concept (FPC) for lakes. Hydrobiologia, 613 (1): 151-170. DOI: 10.1007/s10750-0089480-3

WARD, J. V., K. TOCKNER \& F. SCHIEMER. 1999. Biodiversity of floodplain river ecosystems: ecotones and connectivity. Regulated Rivers: Research \& Management, 15 (1-3): 125-139. DOI: 10.1002/(SICI)1099-1646 (199901/06)15:1/33.0.CO;2-E

XU, L., S. XU, X. HAN, S. LI, H. J. DUMONT \& B.-P. HAN. 2017. Spatial heterogeneity and long-term dynamics of cladoceran ephippia in a monsoonal reservoir, driven by hydrology and eutrophication. Journal of Paleolimnology, 58 (4): 571-584. DOI: 10.1007/s10933-017-9993-8

Con el patrocinio de: 